\title{
An Exploration off Citizen Participation In Policy Making: Barangay Development Plan And Annual Investment Plan Of Maloro, Tangub City
}

\author{
Christine B. Tenorio, MPA
}

Mindanao State University -Iligan Institute of Technology, Iligan City, Philippines tenorio christine@yahoo.com

\begin{abstract}
The Local Government Code of 1991 (RA 7160) empowers local authorities to manage their internal affairs consistent with devolution and local autonomy. In line with this, as implemented by Article 384 the Barangay Maloro must submit a Barangay Development Plan (BDP) and Annual Investment Plan (AIP) to the Department of the Interior and Local Government (DILG). This study delved on measures to elicit the citizen participation of the barangay residents in the planning, implementation and evaluation, the levels of citizen participation, and community issues that has generated citizen participation. Survey and interview were used to generate primary data from the 120 residents of Barangay Maloro, Tangub City. Descriptive and inferential statistical tools were utilized in examining the overall level of participation in planning, implementation and evaluation a higher percentage of the people were observed as less engaged. Furthermore, as manifested in the overall level of participation baranagy residents were observed as less engaged in planning, implementation and evaluation of the Barangay Development Plan (BDP) 2014-2016 and Annual Investment Plan (AIP) 2017. Therefore, the level of citizen participation indicates a medium level of participation which the Barangay Maloro residents were involved either in implementation only or in planning and implementation stage of Barangay Development Plan (BDP) and Annual Investment Plan (AIP). Among the recommendations are for the Barangay Maloro officials to promote community development through citizen involvement.
\end{abstract}

Keywords: Citizen participation; Barangay policy-making; Barangay development plan; Barangay Annual Investment Plan

\section{Introduction}

The concept of citizen participation in the Philippines became prominent in public discourse after the collapse of the Marcos dictatorship and the promulgation of the 1987 constitution (Fabros, 2002). The imposition of Martial Law in late 1972 and its lifting in early 1981 marked another period in Philippine history. It signaled what the President of the Republic termed as the advent of "participatory democracy" (Alfiler, 1982). More notably, citizen participation in the local context, advanced greatly when decentralization reform was introduced in 1991 with the passage of Republic Act 7160, otherwise known as the Local Government Code (Nierras, 2005).

The venue for citizen participation as established under Martial Law the "Barangay" or citizen assembly (Alfiler, 1982). The Barangay was created by the Presidential Decree Nos. 86 and 86A. In which the Barangay known as the lowest political unit consisting of Filipino citizens who are 15 years of age or over, who have been residents in the area for a minimum of six months and are registered in the 
Barangay secretary. The structure and functions of the previous barrios, the predecessors of the Barangay, were adopted for the latter. The Barangay Council is made up of the Barangay chairman and six councilors.

This study explores the citizen participation in policy-making of Tangub City specifically in Barangay Maloro. In this way, it contributes to the understanding in facilitating citizen's participation in policy-making. Thus, serve towards the locality as a tool in good governance.

Objectives of the Study

1. What are the measures to employ citizen participation of the Barangay residents in the policy making process?

2. What are the levels of citizen participation in the different stages of policy making such as planning, implementation and evaluation particularly in the Barangay Development Plan (BDP) and Annual Investment Plan (AIP) of Barangay Maloro?

3. What other issues in the community has generated citizen participation? 


\section{Conceptual/theoretical framework}

Levels of Citizen Participation

Citizen participation is regarded in terms of the program cycle. Presented in a Figure 1 is a continuum of citizen participation.

Areas of Involvement

Passive Active

In the

Program

Cycle

\begin{tabular}{lcc}
\hline $\begin{array}{l}\text { As recipient } \\
\text { of service }\end{array}$ & In & In planning \\
only & implementation & and \\
& only & implementation \\
& & evaluation
\end{tabular}

In Provision

of Resources

Finance

\begin{tabular}{ccc}
\hline $\begin{array}{c}\text { Completely } \\
\text { dependent on }\end{array}$ & $\begin{array}{c}\text { Dependent on } \\
\text { some combination }\end{array}$ & $\begin{array}{c}\text { Completely } \\
\text { self } \\
\text { external }\end{array}$ \\
funding & external and & supporting \\
\end{tabular}

Personnel

$\begin{array}{lcc}\text { Fielded by } & \text { Fielded jointly } & \text { Completely } \\ \text { externally } & \text { by outside agency } & \text { fielded by } \\ \text { based agency } & \text { and local } & \text { local } \\ & \text { community } & \text { community }\end{array}$

Figure 1 Continuum of Citizen Participation

Source: Carino, L. (1982). Integration, Participation and Effectiveness: An Analysis of the Operations and Effectiveness of Five Rural Health Delivery Mechanism. Manila: Philippine Institute for Development Studies.

In Figure 1 Carino and Asscociates (1982:24) mapped a citizen participation three-point continuum, the passive, midpoint indicating "medium" level of participation and active. However, in this study a certain criteria applied in the areas of involvement which is limit only in the program cycle. Thus, passive level of participation is when the residents are (a) involved only as recipients of services in the Barangay Development Plan (BDP) and Annual Investment Plan (AIP). Moreover, citizens or residents considered to have active level of participation when they are (a) involved in the planning, implementation and evaluation in the Barangay Development Plan (BDP) and Annual Investment Plan (AIP). Furthermore a midpoint located 
between passive and active where (a) the residents are involved either in implementation only or in planning and evaluation in the Barangay Development Plan (BDP) and Annual Investment Plan (AIP), (Carino and Asscociates, 1982:24).

\section{Measures to Employ Citizen Participation in Policy Making}

The International Association of Public Participation (IAP2) spectrum presents a five-point continuum of participatory processes: inform, consult, involve, collaborate, and empower. Each point along the spectrum represents a different purpose for citizen participation and has a different level of citizen empowerment or shared decision-making authority.

In this study, information is applied at the first level of the spectrum are processes that inform, or provide the public with balanced and objective information to assist them in understanding the problem, alternatives, opportunities, and solutions. Some examples of informational processes include static websites, mailings, bill stuffers, fact sheets, 311 call centers, and open meeting webcasts. The consultation is applied at the second level of the spectrum. This level involves processes that engage with the public to obtain public feedback, analysis, alternatives, and/or decisions. Moreover, in this process citizen have minimal shared decision authority.

Involvement on the other hand, is applied as at the third level of the spectrum. This entails processes that involve the public through work direct engagement throughout the process. This is to ensure that public concerns and aspirations are consistently factored -in the decisions and actions made by the institution. In this study, collaboration is applied as at the fourth level of the spectrum are processes that collaborate with the public, or partner with the public in each aspect of the decision including the development of alternatives and the identification of the preferred solution.In this study, empowerment is applied as at the highest level of the spectrum are processes that empower the public, or place final decision-making in the hands of the public.

\section{Framework of Policy-Making Process}

Figure 2 illustrates the framework stages of policy making process. This study is looking into the crafting of policy in the process of planning, implementation and evaluation. It begins with the agenda settings which study public or local problems are recognize and defined. This stage will pose a challenge for the local government to action. In response, the local legislative and barangay council responds by formulating, adopting and implementing a strategy for addressing the problem.

On the other hand, Lassen offers four categories of participation namely: participation in the implementation of project, participation in evaluation, and participation in control over how the projects are directed in the long run (Lassen, 1979:3-26; cited in Castillo, 1982:668-669). 


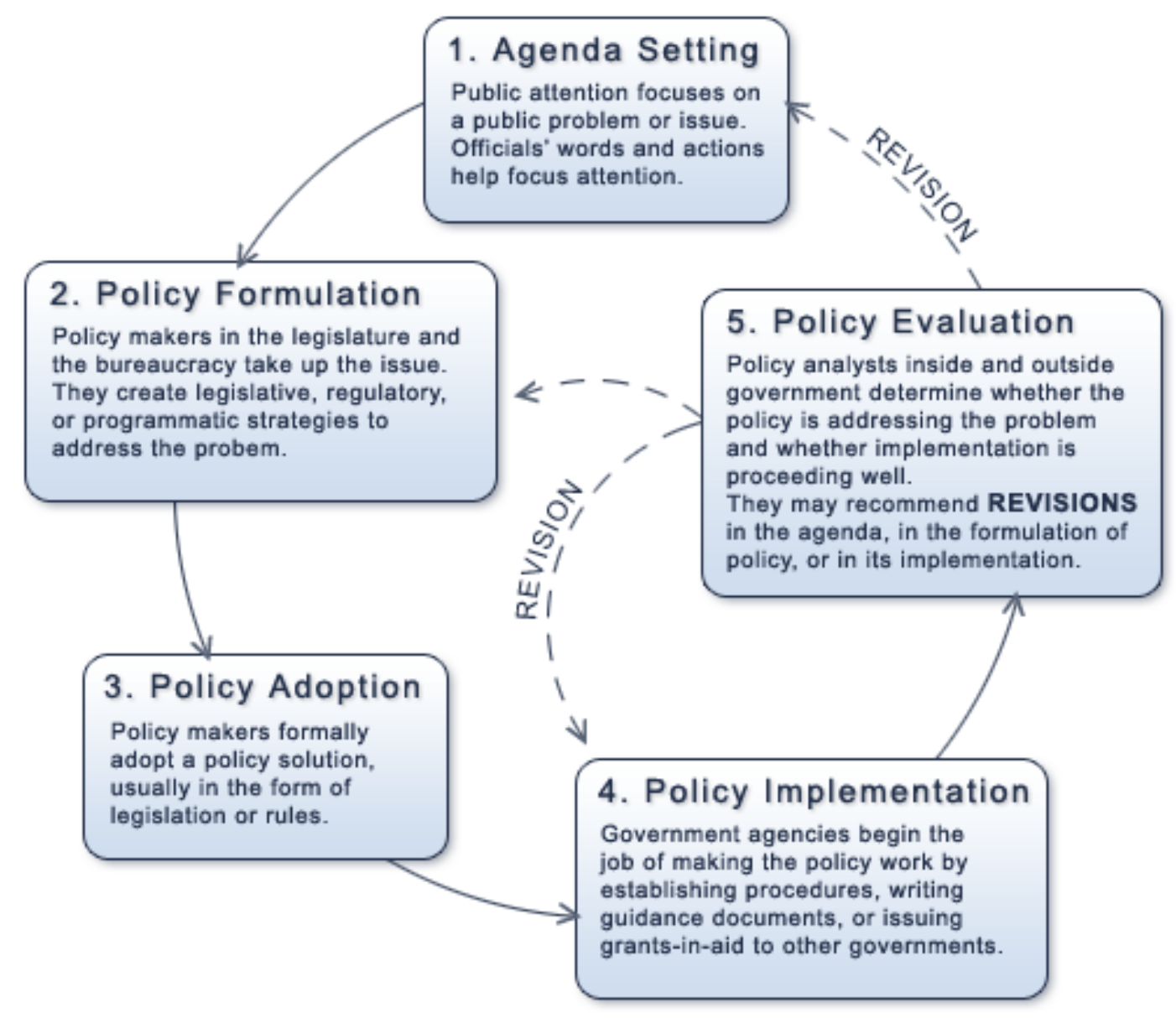

Figure 2 Framework Stages of Policy-making process

Sources: Anderson, J. (1979). Public Policy Making, 2nd ed. New York: Holt, Rinehart \& Winston Inc.,

Community Issues that Generate Citizen Participation

A community is a group of people who has a strong communal interest that binds each other (Babooa, 2008). In this study, community participation involves participation by a group of people belonging to same culture or background within a barangay area. The important part of the community participation process comes to the fore when people recognize the needs and problems they have in common with others. In line with this, the community utilizes in building possibilities to identify and mobilize their own resources in finding solutions to their problems (Masango, 2001a). Hafner (1995:73) studied Community Participation and it was mentioned that efforts to initiate participation projects in Thailand failed, due to an inability to sustain community interest when long-term goals were established and no immediate gratification was available. Moreover, it was also noted that the sustainability of participation was dependent on certain conditions (Lisk 1988:10), such as when it becomes possible to meet long-term goals such as community upliftment and services, expectation of benefits, capable leadership and self-reliance and self-confidence through participation. 


\section{Conceptual Framework}

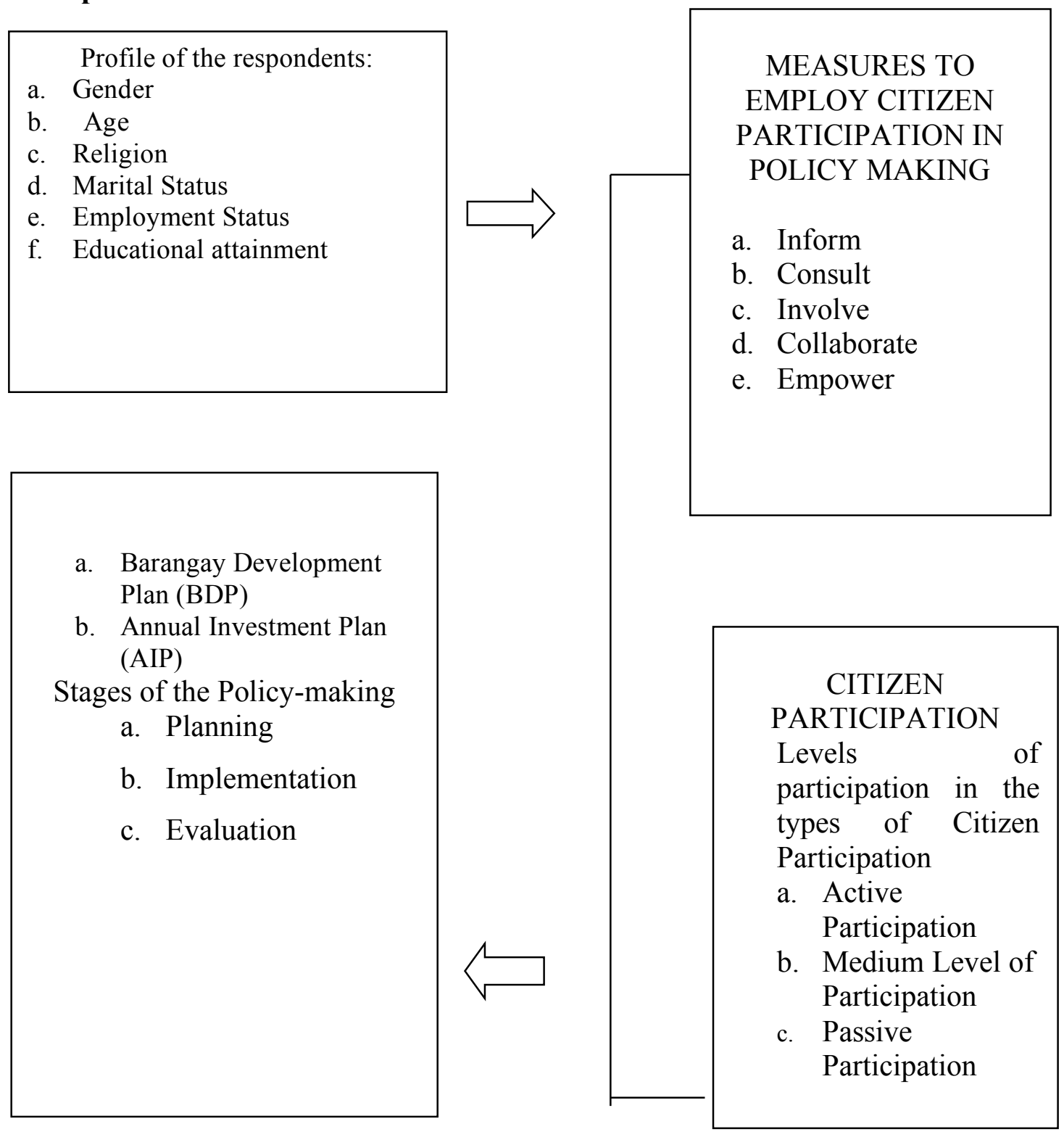

Figure 3 Citizen Participation in Policy Making Conceptual Framework

\section{Research methodology}

This section describes the research design, research setting, research respondents, sampling procedures, research instrument, ethical procedures, data gathering procedure, and treatment and analysis of the gathered data.

\section{Research Design}

This study employed mixed method using descriptive survey design and correlational analysis. The said research design and method of data analysis was chosen because of its applicability in gathering and analyzing the data generated in this study. This design was useful in determining citizen participation in policy making of 
Barangay Maloro, Tangub City. Moreover, the correlational analysis was used to measure the relationships in the profile of the respondents and citizen participation.

\section{Research Setting}

This study was conducted in Barangay Maloro, Tangub City. According to the National Census and Statistics office in Ozamiz the creation of City shows that Tangub City has a total land area of 141.54 square kilometers. Barangay Maloro is bound on the North by Barangay Isidro D. Tan and Barangay Silanga, south by Barangay Migcanaway, on east by Panguil Bay and on the west by Micanaway River. Barangay Maloro of the urban barangays located 800 meters from the City hall. It is composed of seven (7) puroks namely Purok Bougainvilla, Dancing Lady, Orchids, Roses, Golden Shower, Yellowbush, and Vanda with one as a district chairman. It has a total land area of 82, 1062 hectares. Barangay Maloro is headed by the current Barangay Chairman Hon. Liza Balatero.

\section{Research Subjects and Sampling Procedure}

The respondents of this study were the residents of Barangay Maloro, Tangub City and the members of the Barangay Council. Barangay Maloro has a population of 2569 (Maloro Barangay Health Workers, 2016). The researcher selected residents of 18 years and above. The research population of 120 was determined from Puroks Dancing Lady and Yellow Bush in Barangay Maloro. Moreover, using the cluster sampling method $15 \%$ of the population was drawn to determine the respondents. Thus a total population of 803 of two puroks, for Purok Dancing there are 63 respondents while of Purok Yellowbush there are 57 respondents a total of 120 research respondents and they should be above 18 years of age.

\section{Results and discussion}

A scoring procedure was used and three levels of participation were identified: not engaged, less engaged and engaged. Each table represents the percentage of the level of participation in planning, implementation and evaluation stage.

Table 1 shows the level of participation in the planning stage of the Barangay Development Plan (BDP) 2014-2016 and Annual Investment Plan (AIP) 2017.

The planning for BDP and AIP has four subcategories: consultation, involvement, collaboration and empowerment. In line with this, majority or 53 percent of the barangay residents were engaged through being consulted in the planning stage of BDP and AIP. On the other hand, majority or 42 percent of the barangay residents were engaged through being involved in the planning stage of BDP and AIP. Moreover, majority or 55 percent of the barangay residents were not engaged through being collaborated in the planning stage of BDP and AIP. Furthermore, majority or 42 percent of the barangay residents were engaged through being empowered in the planning stage of BDP and AIP. 
Table 1 Level of Participation in Planning of BDP and AIP

\begin{tabular}{|l|c|c|c|c|c|c|c|c|}
\hline \multirow{2}{*}{$\begin{array}{c}\text { Level of } \\
\text { Participation }\end{array}$} & \multicolumn{8}{|c|}{ Planning } \\
\cline { 2 - 10 } & Consultation & \multicolumn{2}{|c|}{ Involvement } & \multicolumn{2}{c|}{ Collaboration } & Empowerment \\
\cline { 2 - 10 } & $\mathrm{f}$ & $\%$ & $\mathrm{f}$ & $\%$ & $\mathrm{f}$ & $\%$ & $\mathrm{f}$ & $\%$ \\
\hline Not Engaged & 35 & 29 & 41 & 34 & 66 & 55 & 44 & 37 \\
\hline $\begin{array}{l}\text { Less } \\
\text { Engaged }\end{array}$ & 22 & 18 & 29 & 24 & 33 & 28 & 26 & 22 \\
\hline Engaged & 63 & 53 & 50 & 42 & 21 & 18 & 50 & 42 \\
\hline Total & 120 & 100 & 120 & 100 & 120 & 100 & 120 & 100 \\
\hline
\end{tabular}

Table 2 shows the level of participation in the implementation stage of the Barangay Development Plan (BDP) 2014-2016 and Annual Investment Plan (AIP) 2017. The implementation for BDP and AIP has two subcategories: involvement and collaboration. In line with this, majority or 82 percent of the barangay residents were not engaged through being involved in the implementation stage of BDP and AIP. Furthermore, majority or 43 percent of the barangay residents were engaged through being collaboration or sharing the decision making during meetings in the implementation stage of BDP and AIP.

Table 2 Level of Participation in Implementation of BDP and AIP

\begin{tabular}{|l|c|c|c|c|}
\hline \multirow{2}{*}{\multicolumn{1}{|c|}{ Level of Participation }} & \multicolumn{4}{|c|}{ Implementation } \\
\cline { 2 - 5 } & \multicolumn{2}{|c|}{ Involvement } & \multicolumn{2}{c|}{ Collaboration } \\
\cline { 2 - 5 } & $\mathrm{f}$ & $\%$ & $\mathrm{f}$ & $\%$ \\
\hline Not Engaged & 98 & 82 & 31 & 26 \\
\hline Less Engaged & 18 & 15 & 38 & 32 \\
\hline Engaged & 4 & 3 & 51 & 43 \\
\hline Total & 120 & 100 & 120 & 100 \\
\hline
\end{tabular}

Table 3 shows the overall level of participation in planning, implementation and evaluation of the Barangay Development Plan (BDP) 2014-2016 and Annual Investment Plan (AIP) 2017. Moreover, majority or 48 percent of the baranagay residents were engaged in the planning stage of BDP and AIP. On the other hand, majority or 37 percent of the barangay residents were engaged in the implementation stage of BDP and AIP. In line with this, majority or 58 percent of the baranagy residents were engaged in the evaluation stage of BDP and AIP. Furthermore, as manifested in the overall level of participation a higher percentage or 43 percent of the baranagy residents were observed as less engaged in planning, implementation and evaluation of the Barangay Development Plan (BDP) 2014-2016 and Annual Investment Plan (AIP) 2017. 
Table 3 Level of Participation in Planning, Implementation and Evaluation of BDP and AIP

\begin{tabular}{|l|c|c|c|c|c|c|c|c|}
\hline \multirow{2}{*}{$\begin{array}{c}\text { Level of } \\
\text { Participation }\end{array}$} & \multicolumn{2}{|c|}{ Planning } & \multicolumn{2}{c|}{ Implementation } & \multicolumn{2}{c|}{ Evaluation } & \multicolumn{2}{c|}{ Overall } \\
\cline { 2 - 10 } & $\mathrm{f}$ & $\%$ & $\mathrm{f}$ & $\%$ & $\mathrm{f}$ & $\%$ & $\mathrm{f}$ & $\%$ \\
\hline Not Engaged & 31 & 26 & 34 & 28 & 38 & 32 & 27 & 23 \\
\hline Less Engaged & 32 & 27 & 42 & 35 & 12 & 10 & 52 & 43 \\
\hline Engaged & 57 & 48 & 44 & 37 & 70 & 58 & 41 & 34 \\
\hline Total & 120 & 100 & 120 & 100 & 120 & 100 & 120 & 100 \\
\hline
\end{tabular}

Data shows that the overall level of participation in planning, implementation and evaluation of the Barangay Development Plan (BDP) 2014-2016 and Annual Investment Plan (AIP) 2017 of Barangay Maloro residents were observed as less engaged.

\section{Conclusion}

Citizen participation in policy making in Barangay Maloro, Tangub City in the planning, implementation and evaluation of the Barangay Development Plan (2014-2016) and Annual Investment Plan (2017) are primarily measured in terms of consultation and acknowledging their concerns through feedback at the planning stage. On the other hand, the theory of International Association of Public Participation (IAP2) on the aspect of collaboration was applied in terms of collaboration of the barangay residents with the Purok President but not with the barangay officials.

Involvement and collaboration in the implementation stage was manifested through the regular attendance of meetings of the barangay residents which ensured the delivery of the public services concerning strategic directions. This supports the theory of Andersons on policy adaption and policy execution involving the barangay residents in the establish procedures during meetings and in the execution of public services and strategic directions of the barangay.

Furthermore, the engagement of the barangay residents is deemed as less engaged or at a medium level because they were involved as the active citizen in addressing their concerns and in the execution of public services such as the clean and green program.

Thus, in the theory of Anderson's framework stages of policy making process the barangay residents were involved in the agenda setting, policy formulation, adoption and implementation for addressing their concerns. Moreover, in the International Association of Public Participation (IAP2) was applied only in terms of collaboration of the barangay residents with the Purok President. In this sense, citizen participation as requisite of the democratic process affects the policy creation, implementation and evaluation of BDP and AIP in Barangay Maloro, Tangub City. 


\section{Recommendations}

In view of this study, the researcher offers the following recommendations:

1. Citizen participation for socio economic issue:

The Barangay Maloro officials promote participation for the development of the community through responding to the needs of the residents and encourage citizen participation. Furthermore, there should be a further research study in relation to socio economic status and citizen participation.

2. Citizen participation for enhancement of collaboration:

The barangay officials collaborate with the residents through regular meetings, checking of attendance and throughout all stages of planning, implementation and evaluation of BDP and AIP.

3. Citizen participation through administration:

All activities of the Barangay Maloro are directed at policy goals realization by strengthening the adaptation of the policy. In line with this, an integrated development plan must reflect the council's vision for the Barangay Development Plan (BDP) and Annual Investment Plan (AIP).

4. Citizen participation for the academe:

The academes conduct researches focus on citizen participation in policy making. In line with this, aside from entrusting the job through the Department of Political Science, they should conduct seminars about the importance of citizen participation at the barangay level.

\section{References}

Abers, R (1998). From Clientelism to Cooperation: Local Government, Participatory Policy, and Civic Organizing in Porto Alegre, Brazil. Politics and Society 26: 511-537.

Alfiler, C. (1982). Factors that Promote or Deter Popular Participation in Development: The Philippine Experience. Philippines.

Angba, H., Adesope A., \& Aboh S. (2009). Effects of socio-economic characteristics of rural youths on their attitudes towards participation in community development projects.International NGO journal. Vol. 4 (8) pp 348-351.

Austin, D. (1956). Influence of Community Setting. In: Neighbourhood Organization for Community Action. The American Sociological Review. 21 (1).

Azfar, O., Kähkönen, S., Lanyi, A., Meagher, P. and Rutherford, D., (2004). Decentralization, Governance and Public Service: The Impact of Institutional Arrangements. In Kimenyi, M.S. and Meagher, P., eds. Devolution and Development: Governance Prospects in Decentralizing States. Aldershot: Ashgate. pp. 19-62

Azfar, O., Kahkonen, S. and Meagher, P. (2001) "Conditions for Effective Decentralized Governance: A Synthesis of Research Findings”, College Park, University of Maryland, IRIS Center, Working Paper No. 256, [Online]. Available at http://www.iris.umd.edu/download.aspx? . Retrieved [October 31, 2015]. 
Baiocchi, G. (2001). Participation, Activism, and Politics:

The Porto Alegre Experiment and Deliberative Democratic Theory. Politics \& Society 29: 43-72.

Bagheria, R., Bahaman, A., Asnarulkhadi, \& A., Ahmad, S. (2009). Community participation in watershed management programs. Journal of Social Science.5(3)pp 251-256.

Bellefeville, G \& Hemingway, D (2006). A co-operative Inquiry into Structural Social Work students' Ethical decisions making in Field Education. Journal of Social Work values and ethics.Vol.3, No 2.

Bronfenbrenner, U. (1994 February). Ecological models of human development. In T. Husen \& T. N. Postlethwaite (Eds.), The international encyclopedia of education (2nd ed., pp. 1643-1647). New York, NY: Elsevier.

Castillo, G. (1982 July). "Changing Rural Institutions and Participatory Development: A Review of the Philippine Experience." Working Paper prepared for the Philippine Institute for Development Studies. pp. 30-40.

Chambers, R. (1992). Rural appraisal: rapid, relaxed and participatory. In Institute of Development Studies, Discussion Paper no.311 [Online]. Available: https://www.ids.ac.uk/files/Dp311.pdf [October 1, 2015]

Cheema, G. S. (2007). Devolution with Accountability: Learning from Good Practices. In: Cheema, G.S. \& Rondinelli, D.A., eds. 2007. Decentralizing Governance: Emerging Concepts and Practices. Washington: Brookings Institution Press. pp. $170-188$

Chingaipe, H. G, \& Msukwa C. (2008). Whose voice?: Citizen Participation and Influence in Public Policy processes in Malawi. Malawi.

Co, Edna. (1998). Raising an Old Question: Is there People's Participation in Local Governance? Philippines: University of the Philippines.

Constantino, R. (1975, September 11). A past revised. Quezon City: Tala Publishing. Pp. 41-43.

De Guzman, R. (1977). “Citizen Participation and Decision-Making Under Martial Law: A Search for a Viable Political System." Philippine Journal of Public Administration. pp. 100-110.

Dye, R. (1978) Community and Cooperatives in Participation. Hants: Gower. pp 80-90.

Dye, T. (1995)Understanding Public policy. Englewood Cliffs: Prentice-Hall. pp 81-83.

Galvin, M., Colvin, R., Robbins, G., \& Eales, K. (2009 August 12). Straight talk to strengthen delivery in the water services sector. The Water Dialogues. South Africa Synthesis Report. pp. 16-17.

Goldbergwood, E. \& Tully, T. (2006).The Structural approach to direct Practice in Social Work: A Social Constructionist Perspectives. $3^{\text {rd }}$ Ed. New York: Colombia University Press. pp. 23-25

Hafner, D. (1995). Participation and Village Reforestation in Thailand. Community Development Journal. 30(1).

Hollnsteiner, M. (1977). "People as Policy Makers: The Participative Dimension in Low Income Housing. " Paper presented at the International Conference in Low 
Income Housing -Technology and Policy. Asian Institute of Technology, Bangkok Thailand.

Huckfeldt, R. R. (1983). Social contexts, social networks and urban neighborhoods: Environmental constraints on friendship choice. American Journal of Sociology, 89(3), 651-669.

Hussien, M.K. (2003). The role of Malawian local government in community development: Development Southern Africa, 20(2) pp 271-282.

Imoh, A. U., James, I., \& Nwachukwu, E. (2009).Comparative Analysis of poverty status of community participation in rural development projects of AkwaIbom State Nigeria. New York Science Journal, 2 (6).

IAP2 (2006). IAP2's Public Participation Toolbox. Thornton, CO: International Association for Public Participation. Available at: [http://iap2 .affiniscape .com/associations/4748/files/06Dec_Toolbox .pdf]. [September 15, 2016].

IAP2 (2007). IAP2 Spectrum of Public Participation. Thornton, CO: International Association for Public Participation. Available at: http://iap2 .affiniscape .com/associations/4748/files/IAP2\%20Spectrum_vertical.pdf.[September 15, 2016].

Irvin, R. A. Stansbury, J. (2004). Citizen Participation in Decision Making: Is it Worth the Effort? Public Administration Review.64 (1): 56- 58.

Kauzya, J.M., (2007). Political Decentralization in Africa: Experiences of Uganda, Rwanda and South Africa. In: Cheema, G.S. \& Rondinelli, D.A., eds. 2007. Decentralizing Governance: Emerging Concepts and Practices. Washington: Brookings Institution Press. pp. 75-91

Kim, K; Hagedom, E. \& Willamson, J. (2004).Participating in Adult Education and Long Life Learning: National Household Education Surveys of 2001 (NCES 2004-050)

Krueger, P., Rogers, R., Hummer, R., Leclere, F, \& Bondhule, S. (2003). Socio economic status and Age: The effect of Income source and Portfolios on U.S Adult mortality. Sociological Forum, Vol. 6.No 3

Lassen, C. (1979 October). "Reading the Asset less Rural Poor”. Development Digest. pp 60-63.

Lohmeier, K. (2013). An exploration of the quality $y$ of citizen participation: Consumer majority boards of community health centers in Iowa. PH.D.THESIS: University of Lowa.

Masango, R. (2001). Public Participation in Policy-making and Implementation with Specific reference to the Port Elizabeth Municipality.DPA Dissertation, University of South Africa [Online]. Available: http://uir.unisa.ac.za/bitstream/handle/10500/18142/thesis masango r.pdf?seq uence $=1$ [September 10, 2015]

Marcos, F. (1973) Notes on the New Society of the Philippines. Manila: Marcos Foundation Inc. pp 18. 
McLeroy, K. R., Bibeau, D., Steckler, A., \& Glanz, K. (1988).An ecological perspective on health promotion programs. Health Education Behavior, 15, 351-377.

Moghadam, V. M. (2002). Citizenship, Civil Society and Women in the Arab Region. Al-Raida. XIX (97-98): 13

Muriu, A. (2013). Decentralization, citizen participation and local public service delivery. Universitätsverlag Potsdam.

Musukwa, H. (2001). Assemblies lack plans. The Nation, 8(208): 1-2

Nabatchi, T. (2012). A Manager's Guide to Evaluating Citizen Participation. Maxwell School of Citizenship and Public Affairs. Syracuse University.

OECD. (2001a). Citizens as Partners: Information, Consultation and Public Participation in Policy-making. Paris: OECD.pp.31-33.

Oladipo, F \& Adekunle, O. (2010). Empirical Determination of Socio-economic Status and its relationship with selected characteristics of rural malefarmers in Kwara state, Nigeria. A Research Journal of Agriculture and Biological Sciences, 6(1):64-76, 2010. INSInet Publication.

Ritter, J. A. (2008). A national study predicting licensed social workers' levels of political participation: The role of resources, psychological engagement, and recruitment networks. Social Work, 53(4), 347-357.

Wall, L, Pettibone, T, \& Kesley, K. (2005). The impact of Socio-economic status on leadership potential in an Agricultural leadership program. Journal of Southern Agricultural Education Research.Vol. 55, No1

Wildavsky, A. (1979). Speaking Truth to Power. Boston, MA: Little, Brown.

Zbinden,S. \& Lee, D. (2005). Paying for Environmental Services: An Analysis of participating in Costa Rica's PSA program.Journal of World Development.Vol. 33, No2.pp255-2 